\title{
A novel vaccine for mantle cell lymphoma based on targeting cyclin D1 to dendritic cells via CD40
}

Jingtao Chen ${ }^{1,2^{*}}$, Gerard Zurawski ${ }^{2}$, Sandy Zurawski ${ }^{2}$, Zhiqing Wang ${ }^{2}$, Keiko Akagawa ${ }^{2}$, Sangkon Oh², Ueno Hideki ${ }^{2}$, Joseph Fay ${ }^{2}$, Jacques Banchereau ${ }^{2,3}$, Wenru Song ${ }^{2,4}$ and A Karolina Palucka ${ }^{2,3}$

\begin{abstract}
Background: Mantle cell lymphoma (MCL) is a distinct clinical pathologic subtype of B cell non-Hodgkin's lymphoma often associated with poor prognosis. New therapeutic approaches based on boosting anti-tumor immunity are needed. $\mathrm{MCL}$ is associated with overexpression of cyclin D1 thus rendering this molecule an interesting target for immunotherapy.

Methods: We show here a novel strategy for the development of recombinant vaccines carrying cyclin D1 cancer antigens that can be targeted to dendritic cells (DCs) via CD40.

Results: Healthy individuals and MCL patients have a broad repertoire of cyclin D1-specific CD4 ${ }^{+}$and $C D 8^{+} T$ cells. Cyclin D1-specific T cells secrete IFN- $\gamma$. DCs loaded with whole tumor cells or with selected peptides can elicit cyclin D1-specific $\mathrm{CD}^{+} \mathrm{T}$ cells that kill MCL tumor cells. We developed a recombinant vaccine based on targeting cyclin D1 antigen to human DCs via an anti-CD40 mAb. Targeting monocyte-derived human DCs in vitro with anti-CD40-cyclin D1 fusion protein expanded a broad repertoire of cyclin D1-specific CD4 ${ }^{+}$and $\mathrm{CD} 8^{+} \mathrm{T}$ cells.

Conclusions: This study demonstrated that cyclin D1 represents a good target for immunotherapy and targeting cyclin D1 to DCs provides a new strategy for mantle cell lymphoma vaccine.
\end{abstract}

Keywords: Mantle cell lymphoma, Cyclin D1, Vaccine, Dendritic cells, Tumor antigen

\section{Introduction}

Mantle cell lymphoma (MCL) is a distinct clinical subtype of B cell non-Hodgkin's lymphoma (NHL) and accounts for approximately $5 \%-10 \%$ of all lymphoma cases. Current treatment is based on standard chemotherapy often combined with monoclonal antibody rituximab, followed by hematopoietic stem cell transplantation [1-3]. Although these treatment regimens can induce a high rate of remission, most patients ultimately relapse and cannot be cured $[4,5]$. Therefore, new therapeutic strategies are needed to improve the overall survival of patients and decrease treatment-associated morbidity.

A key common transforming event in the pathogenesis of MCL is chromosomal translocation $\mathrm{t}(11 ; 14)$ (q13; q32) leading to overexpression of cyclin D1. Cyclin D1 is a cell cycle regulator that is crucial for the G1-S

\footnotetext{
* Correspondence: jtchen@jlu.edu.cn

'Institute of Translational Medicine, the First Hospital, Jilin University,

Changchun 130031, China

${ }^{2}$ Baylor Institute for Immunology Research and Sammons Cancer Center,

Dallas, TX 75204, USA

Full list of author information is available at the end of the article
}

transition. Its overexpression may facilitate the malignant transformation of the lymphoid cell and tumor progression, resulting in the deregulation of cell cycle control by inhibiting the suppressor effect of retinoblastoma 1 (RB1) and the cell cycle inhibitor p27 [6-8]. Although cyclin D1 negative cases have been reported [9-11], cyclin D1 overexpression still is considered a hallmark for MCL [12]. In addition to MCL, cyclin D1 has been detected in a wide variety of lymphoid and myeloid malignancies, including multiple myeloma, acute lymphoblastic leukemia, and hairy cell leukemia [13-15]. Also, it has been detected in other major malignancies, including colorectal, gastric, esophageal, lung, kidney, and breast cancer while little expression is found in normal tissues [16-21].

Several studies have investigated $\mathrm{T}$ cell responses to cyclin D1 and their potential use for immunotherapy [22-24]. Cyclin D1-specific cytotoxic $\mathrm{T}$ lymphocytes (CTLs) have been demonstrated in cancer patients with MCL and colorectal cancer [23,25,26]. CTLs specific for cyclin D1 were successfully generated from HLA-A2 
positive healthy donors and MCL patients. These CTLs efficiently recognized target cells pulsed with their cognate peptide and cyclin D1 expressing tumor cell lines in an HLA-A*0201-restricted manner. More importantly, HLAA*0201 matched, primary cyclin D1 positive tumor cells were efficiently recognized by cyclin D1-specific CTLs [26]. This suggests that cyclin D1 could be considered as a candidate antigen for immunotherapy despite our limited knowledge on the frequency and profile of cyclin D1specific T cells in MCL patients.

Numerous approaches for the therapeutic vaccination of humans with cancer have been developed including autologous and allogeneic tumor cells (which are often modified to express various cytokines), peptides, proteins, and DNA vaccines (reviewed in [27]). Ex vivo-generated dendritic cells (DCs) have been used as therapeutic vaccines in patients with metastatic cancer for over a decade [28]. Importantly, a number of clinical studies have shown that DCs can expand $T$ cells specific for non-mutated selfproteins that are overexpressed in cancer. The experimental success of using DC-specific antibodies to target antigens to individual DC subsets in conjunction with appropriately chosen adjuvant has appealing potential for the design of anti-cancer vaccines. Combined with a powerful adjuvant, vaccinating with one or multiple tumor-derived antigens coupled to DC-specific antibodies may amplify existing responses or break tolerance enabling the generation of protective responses. Studies to date demonstrate the targeting delivery of tumor antigens to DCs and Langerhan's cells (LCs) [29] and the generation of therapeutic anti-tumor immunity [30] in animal models. More importantly, targeting both tumor and control antigens to human DCs ex vivo can lead to efficient antigen presentation and the subsequent generation of $\mathrm{CD}^{+} \mathrm{T}$ cell [31] and $\mathrm{CD}^{+}{ }^{+} \mathrm{T}$ cell $[32,33]$ responses. Furthermore, certain lectin receptors, including Dectin-1, LOX-1, and DC-SIGN, as well as other DC surface molecules (e.g., CD40), can provide additional activation signals to DCs [34-37].

Here, we have investigated specific $\mathrm{T}$ cell responses to the whole cyclin D1 protein, focusing on identifying potential dominant $\mathrm{T}$ cell epitopes. We found that both healthy individuals and MCL patients have a broad repertoire of cyclin D1-specific T cells thus supporting the utility of cyclin D1 as a tumor antigen for immunotherapy. Subsequently, we have developed a novel vaccine based on targeting cyclin D1 to DCs via the human DC surface receptor $\mathrm{CD} 40$ and explore the immune responses generated by this novel vaccine.

\section{Results}

\section{Cyclin D1-specific IFN- $\gamma$ secreting T cells in PBMCs from MCL patients}

To assess the repertoire of cyclin D1-specific T cells, we investigated peripheral blood mononuclear cells (PBMCs) from five MCL patients (Table 1). A 15-mer overlapping peptide library (71 peptides) covering the whole protein was generated based on the cyclin D1 protein sequence (Table 2). PBMCs from patient ACC-2000 were stimulated with individual cyclin D1 peptides. Supernatants were harvested at $48 \mathrm{~h}$, and cultures were continued for 8 days with IL-2 supplement (Figure 1A, B shows the scheme of experiment). At $48 \mathrm{~h}$, we measured IL-2 and IP-10 secretion. As shown in Figure 1A, cytokine responses at $48 \mathrm{~h}$ were low with IP-10, nevertheless, peptide-specific peaks could be detected. These included 15 peptides (marked in the figure) inducing IP-10 production and six peptides inducing IL-2 secretion (Figure 1A).

At day 8 of culture, the cells were rested for 2 days and restimulated for $48 \mathrm{~h}$ to analyze peptide-specific cytokine responses. As shown in Figure 1B, 14/71 peptides elicited strong IFN- $\gamma$ response with up to $1 \mathrm{ng} / \mathrm{ml}$ IFN- $\gamma$ secreted in response to peptide 31 . IL-2 was produced in response to ten peptides (Figure 1B).

Next, we wanted to analyze the frequency and type of $\mathrm{T}$ cells specific to cyclin D1. CFSE-labeled PBMCs from patient ACC-2000 were cultured with cyclin D1 peptides, restimulated at day 11 with respective peptides, and cytokine profiles were measured using multicolor intracellular cytokine assay (ICS) (Figure 1C). Remarkably, 16/71 of the cyclin D1 peptides induced intracellular IFN- $\gamma$ expression by $\mathrm{CD} 4^{+} \mathrm{T}$ cells (Figure 1C). This suggests the presence of cyclin D1-specific Th1 cells in MCL patients. Two out of 71 cyclin D1 peptides also induced intracellular IFN- $\gamma$ expression by $\mathrm{CD}^{+} \mathrm{T}$ cells (Figure 1C). The peptides that could stimulate $\mathrm{CD} 4^{+}$and $\mathrm{CD}^{+} \mathrm{T}$ cells were different (Figure 1C). ICS data were further confirmed by the analysis of peptide-specific cytokine responses assessed in the supernatants of cultures restimulated for $48 \mathrm{~h}$. There, a number of peptides were able to elicit IFN- $\gamma$ secretion (Figure 1C). Next, Luminex ${ }^{\circ}$ results reflecting the IFN- $\gamma$ secretion into supernatants were overlaid with ICS results reflecting the phenotype of IFN- $\gamma$ secreting T cells (Figure 1B). This analysis clearly indicated that $\mathrm{CD}^{+}$and $\mathrm{CD}^{+} \mathrm{T}$ cells recognize different cyclin $\mathrm{D} 1$ epitopes, and that $\mathrm{CD} 4^{+} \mathrm{T}$ cell repertoire is much broader than that of $\mathrm{CD}^{+} \mathrm{T}$ cells. The analysis of PBMCs from the same patient from a second blood draw ACC-2003 obtained 3 months later showed the same repertoire of IFN- $\gamma$ secreting $\mathrm{T}$ cells (Figure 2A, B). Thus, cyclin D1-specific T cell immunity in MCL patients may be long lived.

\section{Cyclin D1-specific T cells in a cohort of MCL patients}

Having identified a broad repertoire of cyclin D1-specific IFN- $\gamma$ T cells in the PBMCs of one patient, we next analyzed PBMCs from a cohort of four additional MCL patients (Table 1). We used Luminex-based cytokine profiling upon PBMC restimulation as illustrated in 
Table 1 Characterization of MCL patients

\begin{tabular}{|c|c|c|c|c|c|c|}
\hline $\begin{array}{l}\text { Patient ID } \\
\text { number }\end{array}$ & Age & Gender & $\begin{array}{l}\text { Prior } \\
\text { Treatment }\end{array}$ & $\begin{array}{l}\text { Ongoing } \\
\text { Treatment }\end{array}$ & $\begin{array}{l}\text { Disease } \\
\text { Stage }\end{array}$ & HLA type \\
\hline $\begin{array}{l}\text { 1. ACC-2000, } \\
\text { ACC-2003 }\end{array}$ & 69 & M & T, Chemo & - & Remission & $\begin{array}{l}A^{*} 0201 B^{*} 1501 * 3503 C^{*} 0303 * 1203 D R B 1^{*} 0401 * 1401 \\
D Q B 1 * 0503 * 0302\end{array}$ \\
\hline 2. ACC-2038 & 54 & M & Chemo & - & Remission & $\begin{array}{l}A^{*} 0201 * 2601 B^{*} 3801 * 5101 C^{*} 0701 * 1203 D R B 1^{*} 1103 * 1301 \\
D Q B 1^{*} 0301 * 0603\end{array}$ \\
\hline 3. ACC-2805 & 58 & M & Chemo & - & Remission & $A^{*} 01^{*} 02 B^{*} 08^{*} 44 C^{*} 05^{*} 07 * 03(17)^{*} 07 \mathrm{DQB} 1^{*} 02$ \\
\hline $\begin{array}{l}\text { 4. ACC- } 2501 \\
\text { ACC-2065 }\end{array}$ & 57 & M & T, Chemo & Chemo & Persistent & $\begin{array}{l}A^{*} 0101 * 0301 B^{*} 4402 C^{*} 0501 D R B 1^{*} 0401^{*} 1501 \\
D Q B 1^{*} 0301 * 0602\end{array}$ \\
\hline 5. ACC-2781 & 66 & M & No treatment & - & $\begin{array}{l}\text { Just } \\
\text { diagnosis }\end{array}$ & $A^{*} 01 * 31 B^{*} 08^{*} 40(60) C^{*} 03^{*} 07 D R B 1^{*} 03^{*} 04 \mathrm{DQB} 1^{*} 02^{*} 0302$ \\
\hline
\end{tabular}

$T$ transplant, Chemo chemotherapy.

All the MCL patients are Caucasian.

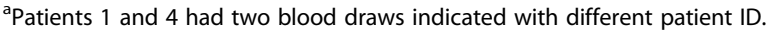

Figure 1B. As shown in Figure 3A, PBMCs from all five analyzed patients displayed cyclin D1-specific secretion of IFN- $\gamma$. PBMCs from most of the patients showed responses to a larger number of peptides $(>10)$ except PBMCs from the patient ACC-2501. While such differences might be related to the precursor frequency and/or might be driven by ongoing treatment; nevertheless, this analysis demonstrates that MCL patients have circulating memory $\mathrm{T}$ cells specific to cyclin D1. Thus, both intracellular staining and secreted cytokine productions established the level of cyclin D1-specific T cells induced by cyclin D1 peptides (Figure 3B). The secretion

Table 2 15-mer cyclin D1 overlapping library

\begin{tabular}{|c|c|c|c|c|c|c|c|c|}
\hline Peptide & Position & Sequence & Peptide & Position & Sequence & Peptide & Position & Sequence \\
\hline 1 & $1-15$ & MEHQLLCCEVETIRR & 26 & $101-115$ & LLGATCMFVASKMKE & 51 & $201-215$ & SMVAAGSWAAVQGL \\
\hline 2 & $5-19$ & LLCCEVETIRRAYPD & 27 & $105-119$ & TCMFVASKMKETIPL & 52 & $205-219$ & AGSWAAVQGLNLRS \\
\hline 3 & $9-23$ & EVETIRRAYPDANLL & 28 & $109-123$ & VASKMKETIPLTAEK & 53 & $209-223$ & VAAVQGLNLRSPNNF \\
\hline 4 & $13-27$ & IRRAYPDANLLNDRV & 29 & $113-127$ & MKETIPLTAEKLCIY & 54 & $213-227$ & QGLNLRSPNNFLSYY \\
\hline 5 & $17-31$ & YPDANLLNDRVLRAM & 30 & $117-131$ & IPLTAEKLCIYTDNS & 55 & $217-231$ & LRSPNNFLSYYRLTR \\
\hline 6 & $21-35$ & NLLNDRVLRAMLKAE & 31 & $121-135$ & AEKLCIYTDNSIRPE & 56 & $221-235$ & NNFLSYYRLTRFLSR \\
\hline 7 & $25-39$ & DRVLRAMLKAEETCA & 32 & $125-139$ & CIYTDNSIRPEELLQ & 57 & $225-239$ & SYYRLTRFLSRVIKC \\
\hline 8 & $29-43$ & RAMLKAEETCAPSVS & 33 & $129-143$ & DNSIRPEELLQMELL & 58 & $229-243$ & LTRFLSRVIKCDPDC \\
\hline 9 & $33-47$ & KAEETCAPSVSYFKC & 34 & $133-147$ & RPEELLQMELLLVNK & 59 & $233-247$ & LSRVIKCDPDCLRAC \\
\hline 10 & $37-51$ & TCAPSVSYFKCVQKE & 35 & $137-151$ & LLQMELLLVNKLKWN & 60 & $237-251$ & IKCDPDCLRACQEQ| \\
\hline 11 & $41-55$ & SVSYFKCVQKEVLPS & 36 & $141-155$ & ELLLVNKLKWNLAAM & 61 & $241-255$ & PDCLRACQEQIEALL \\
\hline 12 & $45-59$ & FKCVQKEVLPSMRKI & 37 & $145-159$ & VNKLKWNLAAMTPHD & 62 & $245-259$ & RACQEQIEALLESSL \\
\hline 13 & $49-63$ & QKEVLPSMRKIVATW & 38 & $149-163$ & KWNLAAMTPHDFIEH & 63 & $249-263$ & EQIEALLESSLRQAQ \\
\hline 14 & $53-67$ & LPSMRKIVATWMLEV & 39 & $153-167$ & AAMTPHDFIEHFLSK & 64 & $253-267$ & ALLESSLRQAQQNMD \\
\hline 15 & $57-71$ & RKIVATWMLEVCEEQ & 40 & $157-171$ & PHDFIEHFLSKMPEA & 65 & $257-271$ & SSLRQAQQNMDPKAA \\
\hline 16 & $61-75$ & ATWMLEVCEEQKCEE & 41 & $161-175$ & IEHFLSKMPEAEENK & 66 & $261-275$ & QAQQNMDPKAAEEEE \\
\hline 17 & $65-79$ & LEVCEEQKCEEEVFP & 42 & $165-179$ & LSKMPEAEENKQIIR & 67 & $265-279$ & NMDPKAAEEEEEEEE \\
\hline 18 & $69-83$ & EEQKCEEEVFPLAMN & 43 & 169-183 & PEAEENKQIIRKHAQ & 68 & $269-283$ & KAAEEEEEEEEEVDL \\
\hline 19 & $73-87$ & CEEEVFPLAMNYLDR & 44 & $173-187$ & ENKQIIRKHAQTFVA & 69 & $273-287$ & EEEEEEEEVDLACTP \\
\hline 20 & $77-91$ & VFPLAMNYLDRFLSL & 45 & 177-191 & IIRKHAQTFVALCAT & 70 & $277-291$ & EEEEVDLACTPTDVR \\
\hline 21 & 84-95 & AMNYLDRFLSLEPVK & 46 & $181-195$ & HAQTFVALCATDVKF & 71 & $281-295$ & VDLACTPTDVRDVDI \\
\hline 22 & 85-99 & LDRFLSLEPVKKSRL & 47 & $185-199$ & FVALCATDVKFISNP & & & \\
\hline 23 & $89-103$ & LSLEPVKKSRLQLLG & 48 & 189-203 & CATDVKFISNPPSMV & & & \\
\hline 24 & $93-107$ & PVKKSRLQLLGATCM & 49 & $193-207$ & VKFISNPPSMVAAGS & & & \\
\hline 25 & $97-111$ & SRLQLLGATCMFVAS & 50 & $197-211$ & SNPPSMVAAGSWAA & & & \\
\hline
\end{tabular}




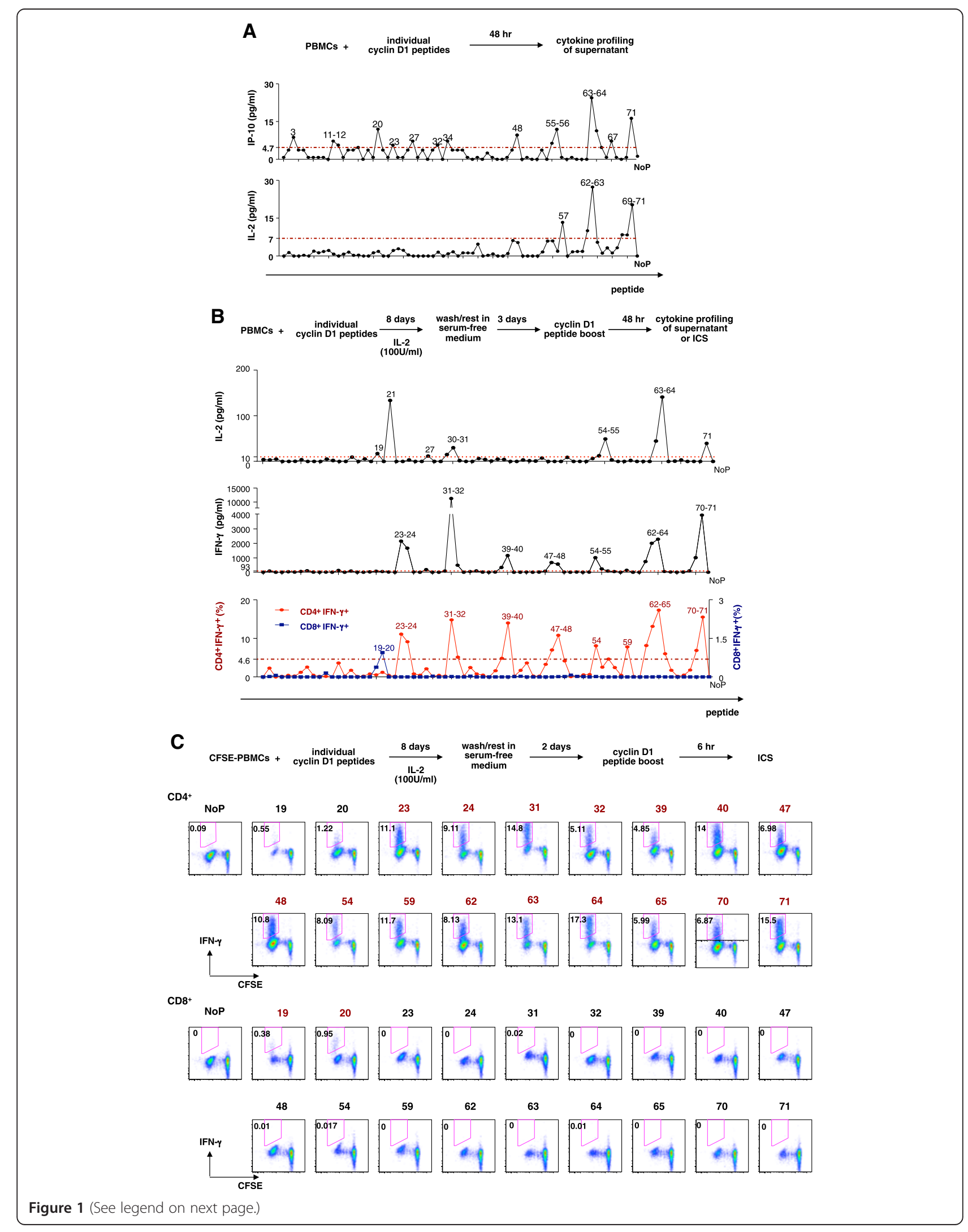


(See figure on previous page.)

Figure 1 Mantle cell lymphoma patients display a broad repertoire of specific T cells to cyclin D1. PBMCs were isolated from a MCL patient (ACC-2000, HLAA* $02010101 * 3201, B^{*} 1501^{*} 3503, C^{*} 0303^{*} 1203, \mathrm{DRB} 1^{*} 0401^{*} 1401, \mathrm{DQB} 1 * 0503^{*} 0302$ ), then $1 \times 10^{6}$ cells per sample were stimulated with 71 individual 15-mer cyclin D1 peptides from Table 2. Median plus 5 multiplied median absolutedeviation (MAD) is considered a positive cutting line (shown as a red dash line). (A) Supernatants were harvested to test IP-10 and IL-2 secretion after 48-h co-culture. NoP is a no peptide negative control. (B) Supernatants of PBMCsafter 48-h boosting were harvested to test cytokine IL-2 and IFN- $\gamma$ secretion by Luminex ${ }^{\circledast}$. The cells without peptide were used as negative control. Percentage of $\mathrm{CD}^{+} \mathrm{IFN}-\gamma^{+}$and $\mathrm{CD} 8^{+} \mathrm{IFN}-\gamma^{+}$population from IFN- $\gamma$ intracellular staining (from (C) was shown in a two-line graph. (C) CFSE-labeled PBMCS were stimulated with cyclin D1 for 8 days and rested in serum-free medium for 2 days before boosting by the same peptide. Intracellular staining of IFN- $\gamma$ was performed $6 \mathrm{~h}$ later. The cells without peptide were used as a negative control.

of cytokines by antigen-specific $\mathrm{T}$ cells was further confirmed by ICS in combination with CD154 staining. As illustrated in Figure 3B, antigen-specific CD154 $\mathrm{CD}^{+} \mathrm{T}$ cells secreted IFN- $\gamma$ and IL-2 in the PBMCs from patient ACC-2805. Similar patterns were found in other patients. In addition, the analysis of PBMCs from five healthy donors (Additional file 1: Table S1) revealed sporadic detection of cyclin D1-specific T cell responses (Additional file 2: Figure S1). Taken together, these results indicate the presence of a broader repertoire of cyclin D1-specific T cells in MCL patients and healthy donors.
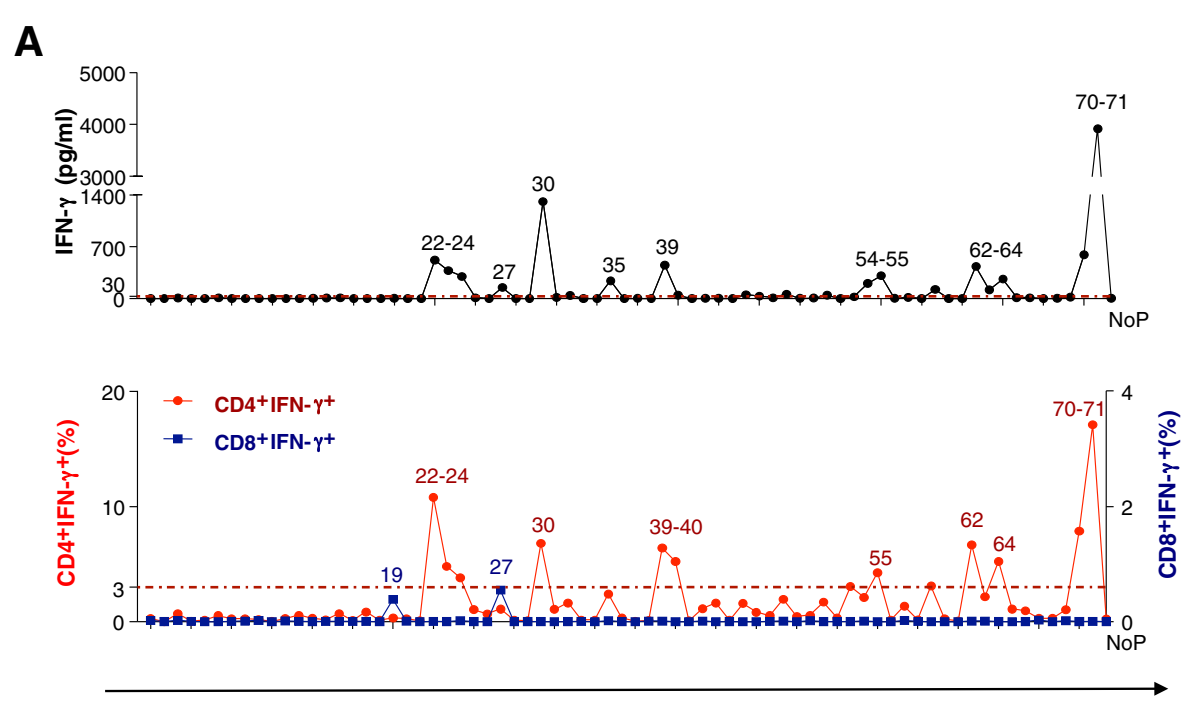

B

peptide

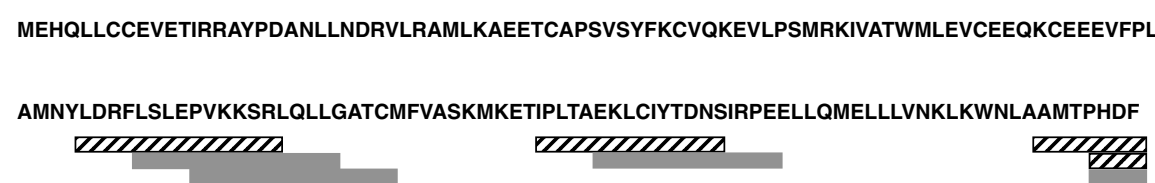

IEHFLSKMPEAEENKQIIRKHAQTFVALCATDVKFISNPPSMVAAGSVVAAVQGLNLRSPNNFLSYYRLTRFLSRVIKCD 27mom

PDCLRACQEQIEALLESSLRQAQQNMDPKAAEEEEEEEEEVDLACTPTDVRDVDI

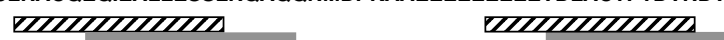

ZZZZZZZZZZZ

ZIIIIZIZIZZ

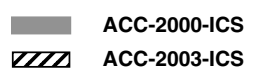

Figure 2 Long live of specific T cells to cyclin D1. (A) Another blood draw 3 months later from the MCL patient ACC-2000, indicated as ACC-2003. IFN- $\gamma$ cytokine secretion and percentage of $C D 4^{+} \mathrm{IFN}-\gamma^{+}$and $\mathrm{CD}^{+} \mathrm{IFN}-\gamma^{+}$population from IFN- $\gamma$ intracellular staining were shown. MAD is considered a positive cutting line (shown as a red dash line). (B) The potential cyclin D1 epitopes that stimulate CD4 ${ }^{+} T$ cells to produce IFN- $\gamma$ based on intracellular staining data are indicated on the protein sequence of cyclin D1. Data shown are two independent experiments by using PBMCs from two blood draws of the same MCL patient. 
A

MEHQLLCCEVETIRRAYPDANLLNDRVLRAMLKAEETCAPSVSYFKCVQKEVLPSMRKIVATWMLEVCEEQKCEEEVFPL

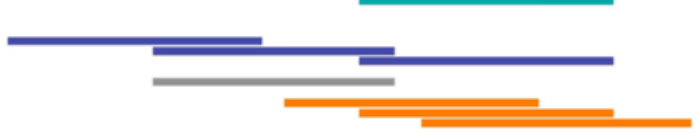

AMNYLDRFLSLEPVKKSRLOLLGATCMFVASKMKETIPLTAEKLCIYTDNSIRPEELLQMELLLVNKLKWNLAAMTPHDF

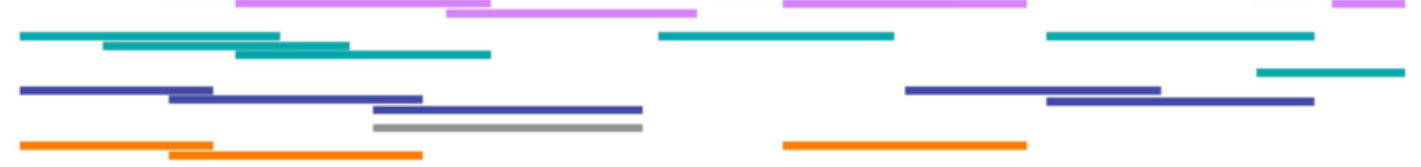

IEHFLSKMPEAEENKQIIRKHAQTFVALCATDVKFISNPPSMVAAGSVVAAVQGLNLRSPNNFLSYYRLTRFLSRVIKCD

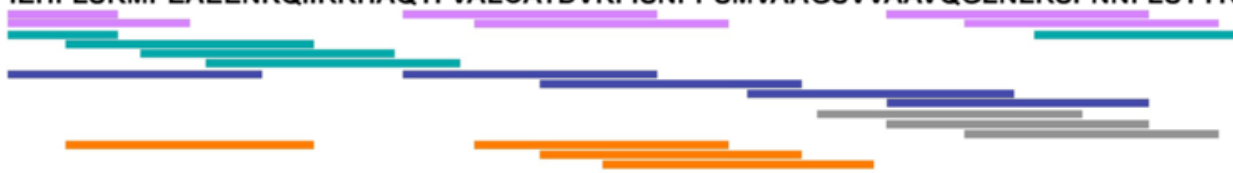

PDCLRACQEQIEALLESSLRQAQQNMDPKAAEEEEEEEEEVDLACTPTDVRDVDI

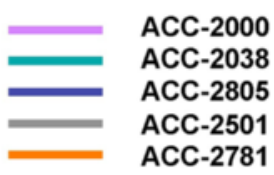

B

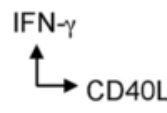<smiles>O=C(O)CC#[W]</smiles>

IFN- $\gamma$

$\stackrel{\leftarrow}{\longrightarrow \mathrm{LL}-2}$
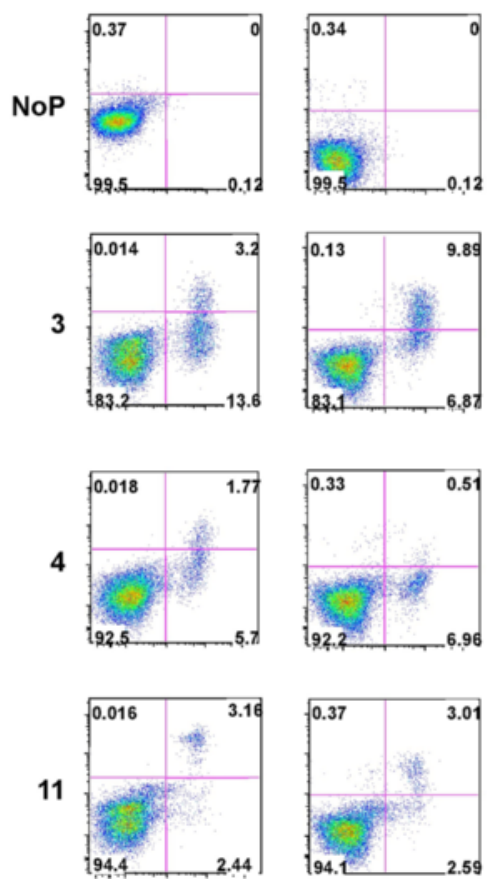

13
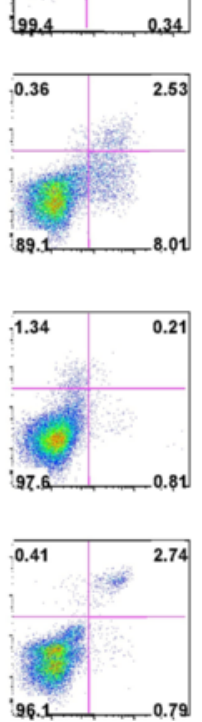

26

27

54
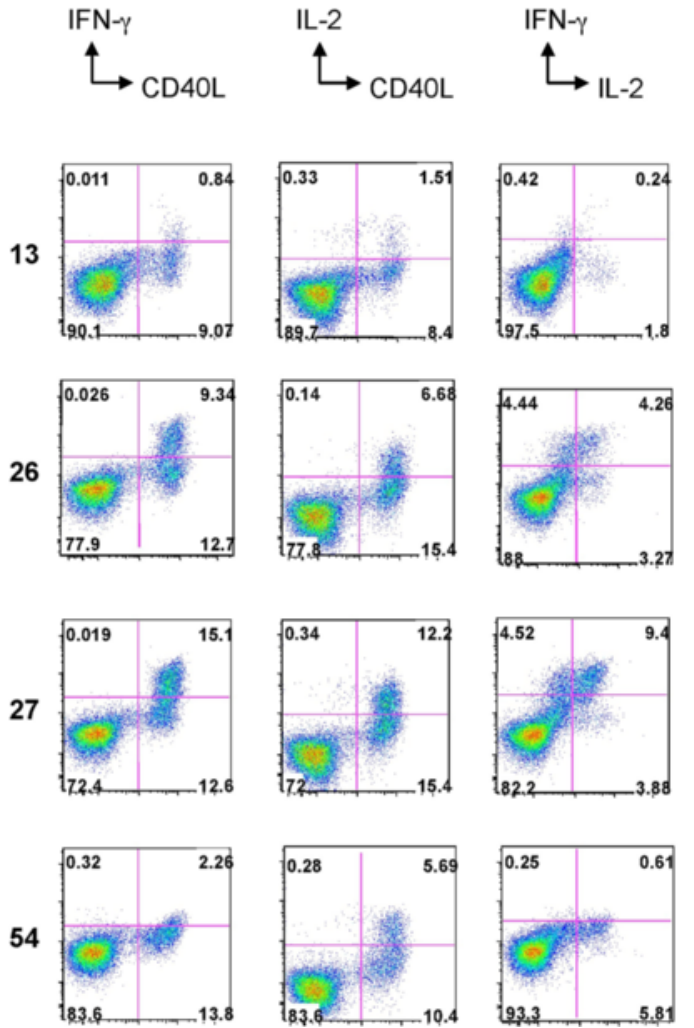

Figure 3 (See legend on next page.) 
(See figure on previous page.)

Figure 3 Cytokine profiles from different MCL patients. (A) The potential cyclin D1 epitopes that induced IFN- $\gamma$ production in PBMCs obtained from five MCL patients on protein sequence of cyclin D1, based on intracellular staining and Luminex ${ }^{\circledast}$ data. (B) Intracellular staining of IFN- $\gamma^{\prime}$ IL-2, and CD40L were performed on a MCL patient ACC-2805 (HLA-A*01*02 $\left.\mathrm{B}^{*} 08^{*} 44 \mathrm{C}^{*} 05^{*} 07 \mathrm{DRB} 1^{*} 03^{*} 07 \mathrm{DQB} 1^{*} 02\right)$. The expressions from CD4 ${ }^{+}$gated were shown. Similar patterns were found in other two patients.

\section{Selection of HLA-A*0201 binding cyclin D1 CD8 ${ }^{+}$T cell epitopes}

Despite detecting cyclin D1-specific T cells, our analysis, thus far, showed a broad $\mathrm{CD} 4^{+} \mathrm{T}$ cell repertoire but a rather narrow $\mathrm{CD}^{+} \mathrm{T}$ cell repertoire in $\mathrm{MCL}$ patients. This could be due to the length of the peptides as class Idependent $\mathrm{CD}^{+}$cells respond better to 8-12-mers. Because CTLs are a major effector arm of anti-tumor immunity, we analyzed in greater detail on the induction of cyclin D1-specific $\mathrm{CD}^{+} \mathrm{T}$ cells from PBMCs of healthy donors. To this end, we selected cyclin D1 peptides which could induce strong IFN- $\gamma$ production as described above and then screened the cyclin D1 sequences for their binding affinity to HLA-A*0201 using peptide-binding databases (http://www.immuneepitope.org). Table 3 shows the sequence of human cyclin D1 peptides that could potentially bind to HLA-A*0201 as deduced by computational predictive binding scores.

The binding affinity of cyclin D1 peptides (Table 3 ) to HLA-A*0201 molecules was determined using the HLAA2 TAP-deficient T2 lymphoma cell line, which enhances HLA-A2 expression when exposed to exogenous HLAA2-binding peptides. This assay confirmed that $\mathrm{P}_{4-13}$, $\mathrm{P}_{58-67}, \mathrm{P}_{100-109}, \mathrm{P}_{123-132}, \mathrm{P}_{99-109}$, and $\mathrm{P}_{202-212}$ can bind HLA-A*0201 molecules (Figure 4A). To test $\mathrm{CD}^{+} \mathrm{T}$ cell responses, $\mathrm{CD}^{+} \mathrm{T}$ cells from a healthy donor (ND239 HLA-A*0201) were expanded by stimulating with DCs loaded with cyclin D1 peptides. Then, T cells were restimulated with peptide-pulsed T2 cells at $37^{\circ} \mathrm{C}$ for $36 \mathrm{~h}$ to test the cytokine production in the supernatant by Luminex ${ }^{\ominus}$. As shown in Figure $3 \mathrm{~B}$, among the seven cyclin D1 peptides able to bind HLA-A*0201 on T2 cells, only $\mathrm{P}_{58-67}$ (KIVATWMLEV), $\mathrm{P}_{57-67}$ (RKIVATWMLEV), and $\mathrm{P}_{99-109}$ (LQLLGATCMEV) could induce cytokine production. Cells pulsed with no peptide were used as negative controls in binding affinity studies and the cytokine release assay (Figure 4A, B). Thus, three cyclin D1 peptides $\mathrm{P}_{58-67}, \mathrm{P}_{57-67}$, and $\mathrm{P}_{99-109}$ could induce potent $\mathrm{CD}^{+} \mathrm{T}$ cell responses.

Next, we assessed whether the identified $\mathrm{CD}^{+} \mathrm{T}$ cell epitopes can be cross-presented to elicit specific CTLs. There, enriched HLA-A*0201 ${ }^{+} \mathrm{CD}^{+} \mathrm{T}$ cells were expanded by GM-CFS/IFN-DCs pulsed with MCL cell line Granta 519 dying bodies. After a single round of stimulation and 10-day culture, the $\mathrm{T}$ cells were tested for their capacity to kill cyclin D1-expressing target cells using a standard ${ }^{51} \mathrm{Cr}$-release assay. Figure $4 \mathrm{C}$ shows that $\mathrm{CD}^{+} \mathrm{T}$ cells could kill Granta $519 \mathrm{MCL}$ cells that were used as the antigenic cargo to load the DCs. Control K562 cells were not killed suggesting CTL lysis. This was further confirmed by the capacity of elicited CTLs to kill T2 cells pulsed with cyclin D1 peptide $\mathrm{P}_{99-109}$ (Figure 4C). Thus, this peptide can be cross-presented and recognized by $\mathrm{CD}^{+} \mathrm{T}$ cells. Though cyclin D1 peptides $\mathrm{P}_{58-67}$ and $\mathrm{P}_{57-67}$ were able to induce cytokine secretion (Figure 4A, B), no killing was observed for these two individual peptides loaded on T2 cells (Figure 4C).

\section{Recombinant fusion protein anti-CD40-cyclin D1 efficiently expands specific $C D 8^{+} \mathrm{T}$ cells}

CD40 is a co-stimulatory molecule belonging to the tumor necrosis factor receptor family and is expressed

\section{Table 3 Potential cyclin D1 peptides for HLA-A*0201} molecules

\begin{tabular}{|c|c|c|c|}
\hline Name & Sequence & Length (mer) & Predictive binding score $^{a}$ \\
\hline$P 5-13$ & LLCCEVETI & 9 & 6.0 \\
\hline P63-71 & WMLEWCEEQ & 9 & 947.8 \\
\hline P151-159 & NLAAMTPHD & 9 & 743.7 \\
\hline P202-210 & MVAAGSWA & 9 & 854.6 \\
\hline P204-212 & AAGSWAAV & 9 & 703.7 \\
\hline P4-13 & QLLCCEVETI & 10 & 133.6 \\
\hline$P 21-30$ & NLLNDRVLRA & 10 & 324.3 \\
\hline P58-67 & KIVATWMLEV & 10 & 255.9 \\
\hline P100-109 & QLLGATCMFV & 10 & 8.3 \\
\hline P101-110 & LLGATCMFVA & 10 & 184.0 \\
\hline P123-132 & KLCIYTDNSI & 10 & 246.9 \\
\hline P154-163 & AMTPHDFIEH & 10 & 981.0 \\
\hline P164-173 & FLSKMPEAEE & 10 & 508.5 \\
\hline P203-212 & VAAGAWAAV & 10 & 580.3 \\
\hline P253-262 & ALLESSLRQA & 10 & 474.4 \\
\hline P57-67 & RKIVATWMLEV & 11 & 354.3 \\
\hline P94-104 & VKKSRLQLLGA & 11 & 582.3 \\
\hline P99-109 & LQLLGATCMFV & 11 & 711.1 \\
\hline P106-116 & CMFVASKMKET & 11 & 339.2 \\
\hline P123-133 & KLCIYTDNSIR & 11 & 362.3 \\
\hline P154-164 & AMTPHDFIEHF & 11 & 904.8 \\
\hline P158-168 & HAFIEHFLSKM & 11 & 577.7 \\
\hline P202-212 & MVAAGSWAAV & 11 & 746.2 \\
\hline P208-218 & WAAVQGLNLR & 11 & 442.9 \\
\hline
\end{tabular}

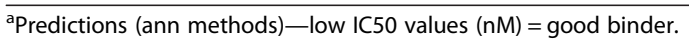




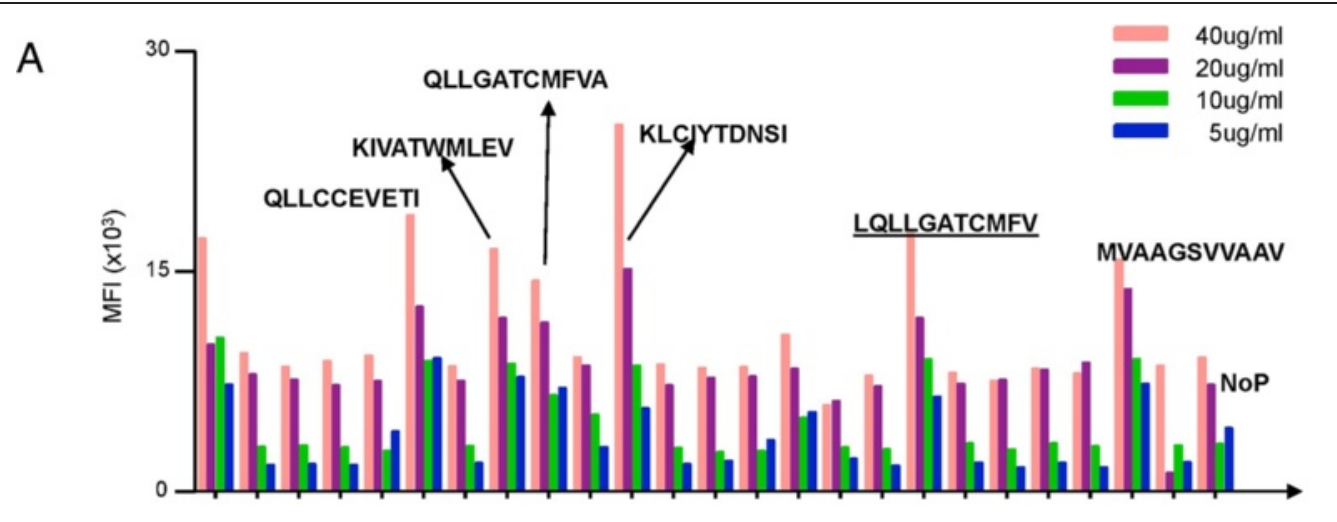

B
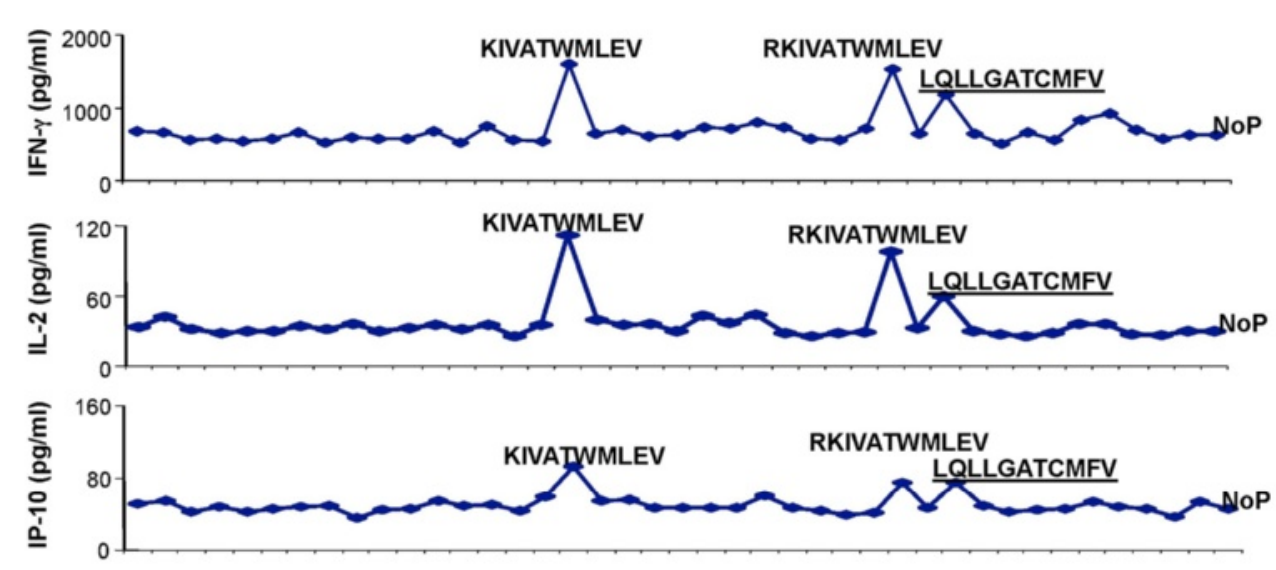

peptide

C

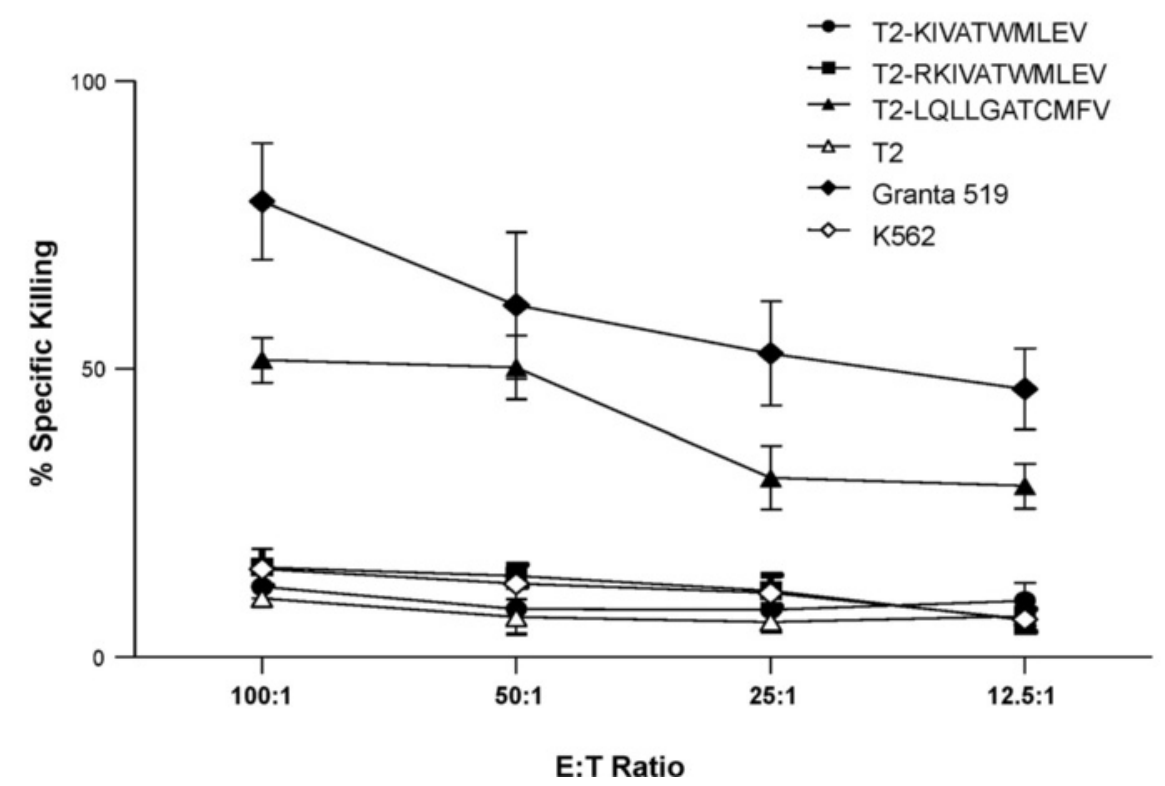

Figure 4 (See legend on next page.) 
(See figure on previous page.)

Figure 4 Identifying dominant HLA-A*0201-restricted cyclin D1 T cell epitopes. (A) Binding capacity for cyclin D1 peptides to HLA-A*0201 molecules on T2 cells. T2 cells were cultured with predicted cyclin D1 peptides which have high binding affinity to HLAAA* 0201 (list in Table 3), in RPMI1604 without FCS for $18 \mathrm{~h}$, and subsequently stained for cell surface expression of MHC class I. Up-regulation of HLA-A2 expression after binding with specific peptides was represented as median fluorescence intensity (MFI). Sequences of positive peptides are shown. (B) IFN-DCs primed by the individual cyclin D1 peptide as (A) were co-cultured with enriched $C D 8^{+} T$ cells for 10 days. Then, cells were boosted with the same peptide pulsed T2 cells at $37^{\circ} \mathrm{C}$ for $36 \mathrm{~h}$, thereafter, supernatant was harvested, and the cytokines production were tested by Luminex ${ }^{\oplus}$. Sequences of positive peptides are shown. (C) Enriched CD8 ${ }^{+}$T cells from a healthy donor ND239 (HLA-A*0201) were stimulated with autologous IFN-DCs pulsed with MCL lymphoma cell dying bodies (Granta 519) and treated with LPS for 6 h. Ten days later, induced specific CTLs were tested in a standard 4-h ${ }^{51} \mathrm{Cr}$ release assay. Target cells used were cyclin D1 peptide $\mathrm{P}_{58-67}$ KIVATWMLEV-pulsed T2 cells, $\mathrm{P}_{57-67}$ RKIVATWMLEV-pulsed T2 cells, P99-109 QLLGATCMFV-pulsed T2 cells, non-pulsed T2 cells, cyclin D1 ${ }^{+} H L A-A^{*} 0201^{+}$MCL lymphoma cell line Granta 519 , and K562 as natural killing activity controls.

on many cells including DCs, monocytes, and B cells $[38,39]$. Anti-CD40 mAbs were able to facilitate the maturation of DCs, and DCs mediated $\mathrm{T}$ cell activation [40-42]. Delivery of antigen via mAb to CD40 has been shown to induce antigen-specific immune responses and provide protection against cancer [43], as well as control HIV infection in vitro [44]. Thus, to explore the potential of this novel vaccine, large cyclin D1 domains were fused to the heavy chain of anti-CD40 Abs (anti-CD40cyclin $\mathrm{D} 1 \mathrm{mAb}$ ) along with isotype control, IgG4 mAbs. Figure 5A shows the construction of these fusion proteins. Domain 1 was fused to DC receptor CD40 or isotype control IgG4, generating anti-CD40-cyclin D1pepA and IgG4-cyclin D1-pepA protein. Domains 2, 3, and 4 were fused to $\mathrm{DC}$ receptor $\mathrm{CD} 40$ or isotype control IgG4, generating anti-CD40-cyclin D1-pepB and IgG4cyclin D1-pepB protein. Together, these two anti-CD40 fusion proteins carried the entire cyclin D1 sequence.

We next tested whether cyclin D1 could be presented to the DC surface by the fusion proteins. GM-CSF/IFN alpha monocyte-derived DCs (IFN-DCs) were first incubated with fusion proteins for $30 \mathrm{~min}$ on ice to prevent internalization, cyclin D1 presented on the surface of DCs was detected by anti-human IgG Abs (Figure 5B), and confirmed by using anti-human cyclin D1 Ab (Figure 5C). Anti-human-cyclin D1 mAb (clone: G124326) recognized anti-CD40-cyclin D1-pepB, but not anti-CD40-cyclin D1-pepA, IgG4-cyclin D1-pepA, and IgG4-cyclin D1-pepB (Figure 5C). Anti-human-cyclin $\mathrm{D} 1 \mathrm{mAb}$ is a monoclonal antibody, which recognized full length cyclin D1, so it may not identify the short part of cyclin D1 presented by anti-CD40-cyclin D1-pepA. Isotype control IgG4-cyclin D1-pepA and IgG4-cyclin D1-pepB could not present to the DC surface.

In addition, the expression of activation markers and co-stimulatory molecules (CD83, CD86, CD80, HLA-DR, and CCR7) on IFN-DCs was significantly increased by $48 \mathrm{~h}$ after co-culture with anti-CD40-cyclin D1 Abs (Figure 5D). This data demonstrated the activating properties of recombinant anti-CD40-cyclin D1 fusion proteins compared to the matching IgG4 control fusion proteins.
Subsequently, the targeting ability of CD40-cyclin D1 recombinant fusion protein to DCs was investigated for the capacity to activate cyclin D1-specific T cells from healthy individuals. IFN-DCs targeted with anti-CD40cyclin D1 mAb expanded a broad repertoire of cyclin D1-specific $\mathrm{CD}^{+}$and $\mathrm{CD} 8^{+} \mathrm{T}$ cells (Figure $6 \mathrm{~A}, \mathrm{~B}$ ).

To examine the cytolytic capability of cyclin D1specific $\mathrm{CD}^{+} \mathrm{T}$ cells, we assessed the functional capacity of prototype vaccine-expanded $\mathrm{CD}^{+}{ }^{+} \mathrm{T}$ cells to produce effector cytokines, cytolytic factors, and degranulation capacity as determined by externalization of CD107a. IFN-DC presented anti-CD40-Cyclin D1 to $\mathrm{T}$ cell cultures from a healthy donor; in response to peptide challenge, cyclin D1-specific $\mathrm{CD}^{+} \mathrm{T}$ cells positive for $\mathrm{CD} 107 \mathrm{a}$ and granzyme $\mathrm{B}$ with IFN- $\gamma$ were induced (Figure 6A, B).

Collectively, these data demonstrate the capacity of anti-CD40-cyclin D1 recombinant fusion proteins to expand cyclin D1-specific $\mathrm{CD} 4^{+}$and $\mathrm{CD} 8^{+} \mathrm{T}$ cells. Currently, the anti-CD40-cyclin D1 recombinant vaccine is being tested in vivo in non-human primates. This strategy will facilitate the development of a mantle cell lymphoma vaccine.

\section{Discussion}

The better understanding of anti-tumor immune response and tumor immune escape mechanisms and the exploration of new ways for different effects and mechanisms of tumor immunotherapy and immunotherapy will facilitate new and innovative approaches to human tumor immunotherapy. Immunotherapy is moving to the vanguard of cancer therapy. Cancer immunotherapy is being increasingly used to drive the immune system to treat tumors [45], and tumor antigens are the most appropriate targets for cancer immunotherapy [46]. The antigen of interest can be used to vaccinate as a whole protein or with synthetic peptides derived from this protein. Presentation of $\mathrm{T}$ cell epitopes on MHC complexes can successfully induce $\mathrm{T}$ cell responses. $\mathrm{T}$ cells specific to subdominant epitopes have been shown to participate in anti-tumor immune responses [47]. 


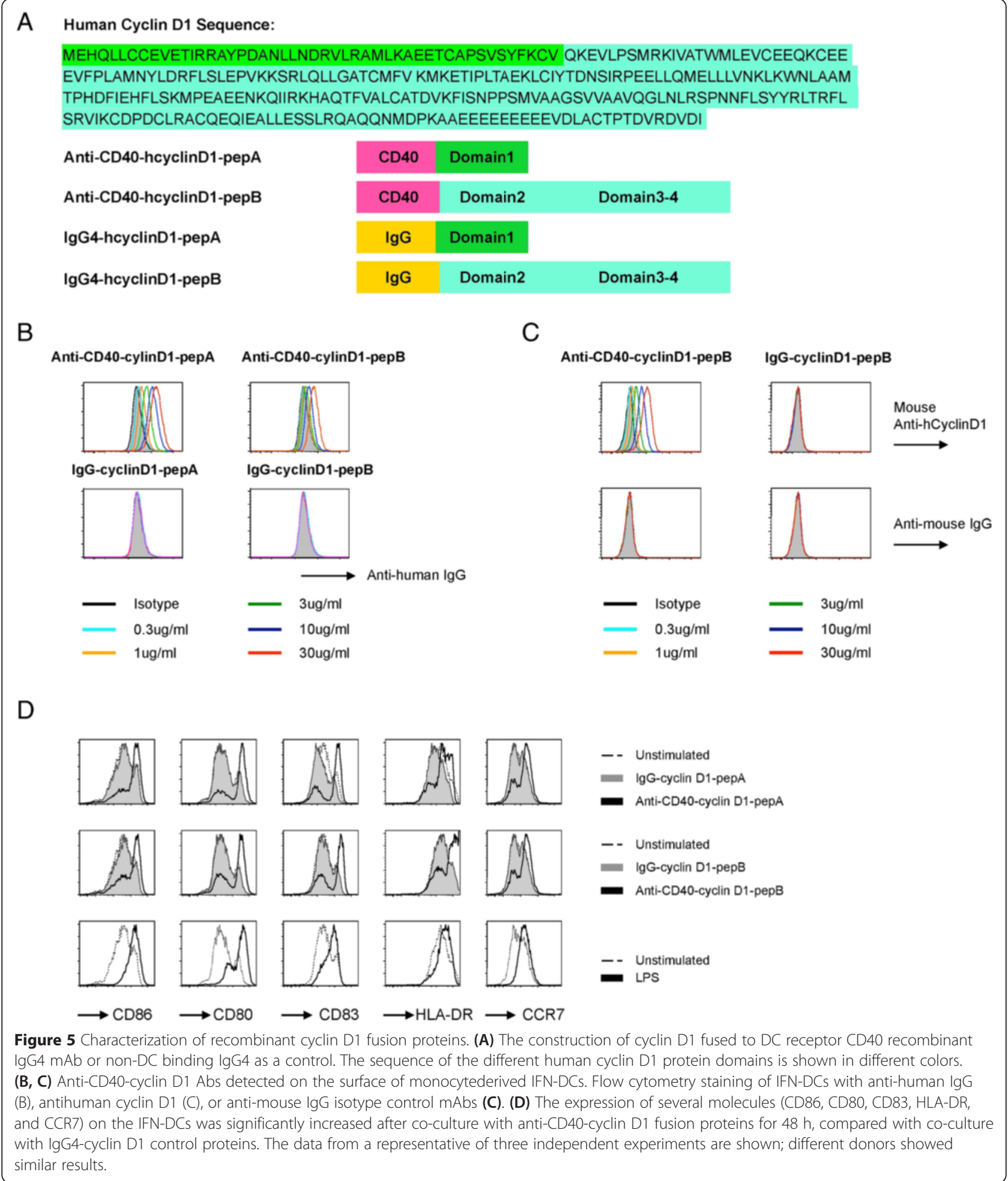

The first clinical trial of a melanoma antigen gene-1 (MAGE-1)-derived peptide-based vaccine was reported in 1996 [48]. Afterward, numerous clinical trials of peptide vaccines have been carried out to assess the ability of these vaccines to induce clinical responses in different cancer patients, and some promising clinical responses have been observed. A number have already received FDA approval, including a personalized peptide vaccination protocol [49]. Peptides recognized by CTLs or helper T cells are generally derived from fragments of tumor antigen 


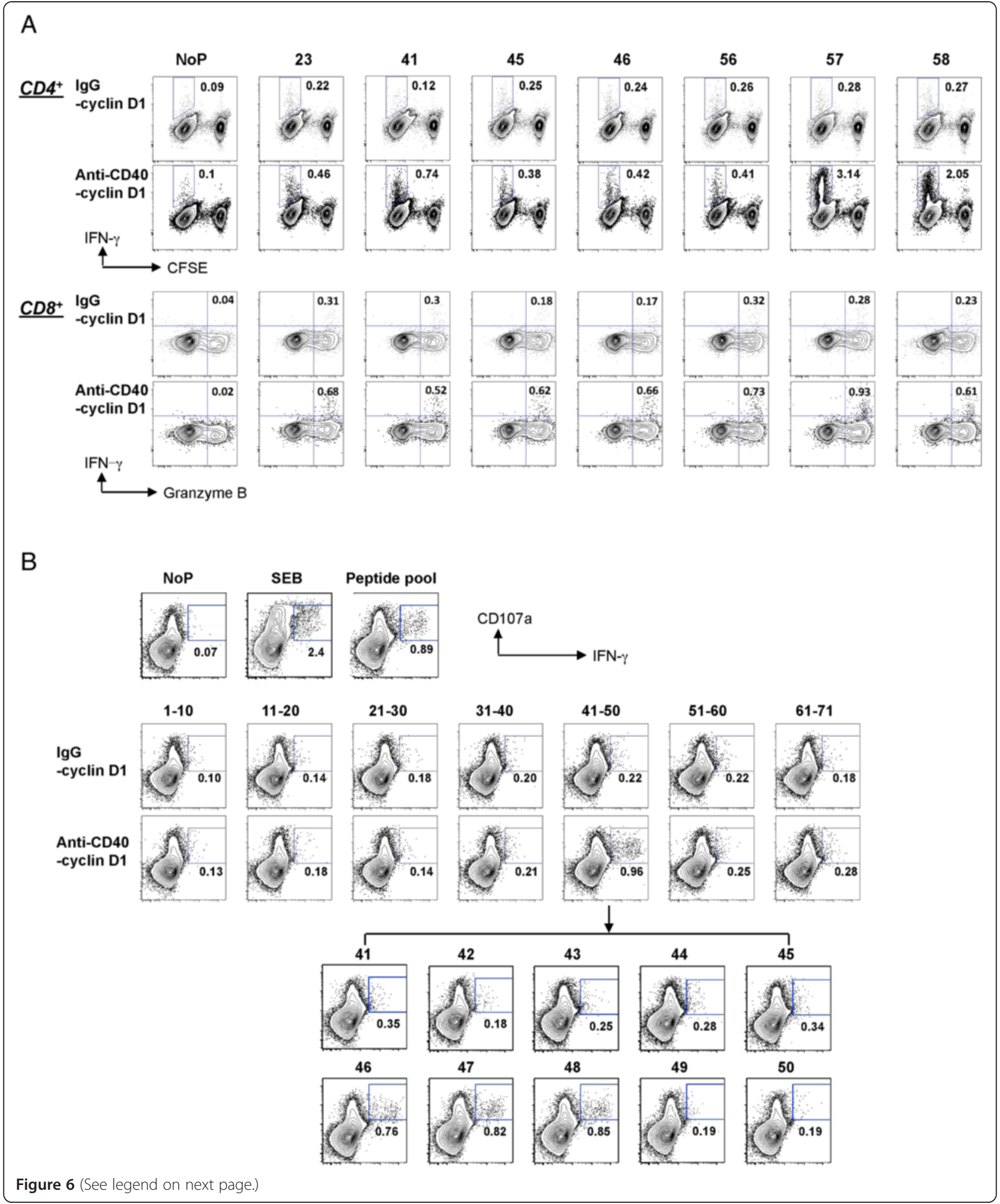


(See figure on previous page.)

Figure 6 Targeting cyclin D1 to DCs via CD40 elicits cyclin D1-specific CD4 ${ }^{+}$and CD8 ${ }^{+} T$ cell responses. (A) $5 \times 10^{3}$ IFN-DCs were loaded with 3 $\mu \mathrm{g} / \mathrm{ml}$ recombinant cyclin D1 fusion proteins or control IgG-cyclin D1. After 8 h, CFSE-labeled autologous enriched CD3 ${ }^{+} \mathrm{T}$ cells were co-cultured for 7 days then added the same amount of cyclin D1 fusion protein or control IgG-cyclin D1-loaded IFN-DCs cultured for another 7 days. Cells were boosted by 71 of 15-mer cyclin D1 peptides following 2-day resting in serum-free medium. Intracellular staining of IFN- $\gamma$ was performed $8 \mathrm{~h}$ later. The cells without peptide boosting were used as a negative control. The percentage of IFN- $\gamma^{+} \mathrm{CFSE}^{-}$cells in gated CD4 ${ }^{+} \mathrm{T}$ cells and IFN- $\gamma^{+}$Granzyme $B^{+}$cells in gated $C D 8^{+} T$ cells were indicated. This data is a representative of three independent experiments of a healthy donor ND257 (HLA-A*0201). (B) Intracellular staining of IFN- $\gamma / C D 107 a$ performed in another healthy donor ND239 (HLA-A*0201) was shown. Percentage of IFN- $\gamma^{+} \mathrm{CD} 107 a^{+}$cells from $\mathrm{CD}^{+}$gated is indicated.

proteins, and an increasing variety of non-classical events were shown to contribute to the production of these peptides [50]. A database containing human antigenic peptides which aims to guide scientists and clinicians searching for appropriate cancer vaccine candidates is available and is constantly being updated [46].

Here, we expanded cyclin D1-specific IFN- $\gamma$ secreting T cells in PBMCs from MCL patients, as well as from healthy donors. A number of cyclin D1 peptides were able to stimulate IFN- $\gamma$ production and showed a broad $\mathrm{CD}^{+} \mathrm{T}$ cell repertoire but a narrow $\mathrm{CD}^{+} \mathrm{T}$ cell repertoire. To do more analysis, crucial for an effective vaccine therapy, we screened peptides based on MHCbinding algorithms and cytokine secretion. Three cyclin D1 peptides $\mathrm{P}_{58-67}, \mathrm{P}_{57-67}$, and $\mathrm{P}_{99-109}$ induced potent $\mathrm{CD}^{+} \mathrm{T}$ cell responses. One of these peptides, $\mathrm{P}_{99-109}$, could be cross-presented and recognized by $\mathrm{CD}^{+} \mathrm{T}$ cells. In accord with our results, HLA-A*0201-binding cyclin D1 epitopes were also previously reported [23,24,26]. The HLA-DR4-restricted T cell epitope $\mathrm{P}_{198-212}$ : NPP SMVAAGSVVAAV derived from cyclin D1 epitope was identified by mass spectrometry [22]. Thus, our results highlight the importance of verifying the functional peptide sequences in vaccines. The finding that immune reactivity against cyclin D1 was also found in healthy donors could mean that cancer patients have a high frequency of cyclin D1-specific T cell precursors in the blood, potentially leading to a higher efficacy of cyclin D1-targeted anti-tumor vaccination.

Dendritic cells (DCs) are specialized in antigen processing and presentation. DC-based experimental cancer vaccines have shown some success in patients with lymphoma and other cancers. Numerous receptors are expressed on DCs, including three categories: receptor kinases, toll-like receptors (TLRs), and C-type lectin receptors. By targeting these DC receptors, a more competent approach of delivering antigens in DC-based anti-cancer immunotherapy is becoming a promising vaccination strategy. The specific targeting of antigens to DCs in vivo could enhance potent antigen-specific $\mathrm{CD}^{+}$and $\mathrm{CD}^{+} \mathrm{T}$ cell-mediated immunity [51-53]. DC targeting not only assists the delivery of an antigen but also potentially provides an activation signal by targeting activating DC receptor antibodies [45].
In this context, cyclin D1 is a promising tumorassociated antigen (TAA) for MCL. It is consistently overexpressed in virtually all MCL patients. Moreover, the presence of cyclin D1-specific $\mathrm{CD}^{+} \mathrm{T}$ cells in MCL patients is proven. Our previous study using antiCD40.HIV5pep antibody, which has a physical linkage between the five long HIV peptides from Gag, Nef, and Pol with the CD40-targeting antibody, could also induce HIV-specific $\mathrm{T}$ cells in vitro [44]. In order to develop a specific immune response against $\mathrm{MCL}$, recombinant cyclin D1 antigen carried by an anti-DC receptor vehicle CD40 was delivered to IFN-DCs for MHC class-I crosspresentation in $\mathrm{T}$ cell co-cultures. This resulted in the expansion of antigen-specific $\mathrm{CD}^{+} \mathrm{T}$ cells, which were evaluated by measuring the production of cytokines following peptide stimulation. In response to peptide challenge, most antigen-specific $\mathrm{CD}^{+} \mathrm{T}$ cells expressed granzyme $\mathrm{B}$ and CD107a with IFN- $\gamma$, establishing the cytotoxic capability of cyclin D1-specific $\mathrm{CD}^{+} \mathrm{T}$ cells. Antigen-specific $\mathrm{CD}^{+}{ }^{+} \mathrm{T}$ cells also could expand via this prototype vaccine. Thus, our results demonstrated that targeting cyclin D1 to DCs could efficiently induce and activate cyclin D1-specific T cells.

Taken together, these approaches will facilitate the development of a novel DC vaccine for MCL. Mounting a potent cellular immune response in MCL patients is expected to bring better clinical benefits to patients.

\section{Materials and methods \\ Study subjects}

Five healthy donors and five MCL patients were studied. Their demographics and HLA types are listed in Table 1. All MCL patients are cyclin D1 positive. Apheresis and blood draws were obtained according to IRB-approved protocol (002-108) at Baylor Research Institute (Dallas, TX). All donors signed informed consent forms. Peripheral blood mononuclear cells (PBMCs) were purified by Ficoll (Amersham Biosciences, Pittsburgh, PA) density gradient centrifugation and cryopreserved until use. Total T cells or $\mathrm{CD}^{+} \mathrm{T}$ cells were enriched by negative selection following manufacture protocols with an EasySep Human T cell Enrichment kit or EasySep Human CD8 ${ }^{+}$ T cell Enrichment kit (Stem Cell Technologies Inc.) to purity $\geq 98 \%$. 


\section{Peptide synthesis}

The overlapping 15-mer cyclin D1 peptide library (Table 2) was staggered every four amino acids along the entire cyclin D1 sequence and generated at Mimotopes (Clayton, Australia). Peptides were dissolved in 5\% acetonitrile (Sigma) at $10 \mathrm{mM}$ and stored at $-80^{\circ} \mathrm{C}$.

\section{Media and reagents}

Complete culture medium (CM) consisted of RPMI 1640 medium (Invitrogen, Carlsbad, CA), 1\% L-glutamine (Sigma), 1\% penicillin/streptomycin (Sigma), $50 \mathrm{mM} \mathrm{2-}$ mercaptoethanol (Sigma), 1\% sodium pyruvate (Sigma), $1 \%$ nonessential amino acids (Sigma), and 10\% heatinactivated FBS (fetal bovine serum, GIBCO). For T cell cultures, FBS was replaced by $10 \%$ heat-inactivated human serum AB (Gemcell). IL-2 (Genzyme) was used at $100 \mathrm{IU} / \mathrm{ml}$. FITC mouse anti-human cyclin D1 antibody (G124-326) was purchased from BD Pharmingen.

\section{Cell lines}

Granta 519 (mantle cell lymphoma cell line), K562, and T2 (HLA-A2-positive cell line) cells were purchased from the American Type Culture Collection (Manassas, VA). Cell lines were cultured in CM.

\section{Intracellular cytokine assay}

Cultured PBMCs were restimulated with individual cyclin D1 15-mer peptides for $2 \mathrm{~h}$. Then, Golgi-plug (BD Pharmingen) was added to the cultures and followed by another 4-h culture. After a total $6 \mathrm{~h}$ of stimulation, cells were harvested, surface stained with CD4 and CD8 mAbs, then fixed and permeabilized with Cytofix/Cytoperm solution (BD). Finally, the cells were stained intracellularly with anti-IFN- $\gamma$ mAb (BD Pharmingen). The cells were acquired on Canton II or LSRII flow cytometer (BD Bioscience, San Jose, CA) and analyzed using FlowJo software (Treestar, Ashland, OR). When cultured $\mathrm{T}$ cells were analyzed, IFN-DCs were first loaded with cyclin D1 15-mer peptides for $1 \mathrm{~h}$ and then used to stimulated T cells.

\section{Peptide binding assay}

The human TAP-deficient HLA-A*0201 ${ }^{+}$T2 cell line was used to measure the binding ability of cyclin D1 peptides to HLA-A*0201 molecules as described previously [54]. Briefly, $1 \times 10^{5}$ T2 cells per well were incubated in a 96-well plate with or without individual peptides at a concentration of $25 \mu \mathrm{g} / \mathrm{ml}$ overnight. Then the cells were harvested, washed twice with FACS buffer, and stained with a PE-conjugated anti-HLA-A2 antibody (BB7.2; BD Pharmingen, San Diego, CA). The mean fluorescence intensity of HLA-A2 staining was analyzed by LSRII.

\section{Analysis of T cell responses by analysis of cytokine release}

T2 cells were pre-loaded with $10-\mu \mathrm{M}$ peptides for $2 \mathrm{~h}$, washed with PBS twice, then cultured with effector cells at 1:1 ratio in a total volume of $200 \mu \mathrm{l}$ medium with PMA (phorbolyristate acetate, $100 \mathrm{ng} / \mathrm{ml}$ ). Culture supernatants were harvested $36 \mathrm{~h}$ later and tested for IL-2, IFN- $\gamma$, and IP-10 production via cytokine multiplex analysis.

\section{Preparation of killed MCL lymphoma cells}

A $2 \times 10^{5}$ cells $/ \mathrm{ml}$ of the MCL cell line Granta 519 was treated with Velcade (Bortezomib, LC Laboratories) at $0.2 \mu \mathrm{g} / \mathrm{ml}$ for $17 \mathrm{~h}$ at $37^{\circ} \mathrm{C}$. The obtained killed Granta 519 cells, a mixture of apoptotic and necrotic cells, were prepared in batches and frozen and stored in liquid nitrogen. Annexin V and propidium iodide (PI) staining was used to measure death of the lymphoma cells.

\section{Generation of CTLs and cytotoxicity assay}

IFN-DCs were generated from elutriated monocytes by culturing in CellGenix medium (CellGenix) supplemented with $100 \mathrm{ng} / \mathrm{ml}$ human granulocyte-monocyte colony-stimulating factor (GM-CSF, Berlex Laboratories Inc.) and $500 \mathrm{U} / \mathrm{ml}$ IFN- $\alpha$ (INTRONA, Schering Corp) for 3 days. IFN-DCs were loaded with killed Granta 519 cells in a 2:1 ratio for $6 \mathrm{~h}$, then cultured with autologous enriched $\mathrm{CD}^{+} \mathrm{T}$ cells at a 1:25 ratio, and supplemented with IL-7 $(10 \mathrm{IU} / \mathrm{ml})$ and IL-2 $(10 \mathrm{IU} / \mathrm{ml})$ at day 3 and IL-2 only at the second week. T cells were restimulated on day 7. The CTL activity was measured in a standard 4-h ${ }^{51} \mathrm{C}$-release assay at day 14 . Briefly, T2 cells were loaded with or without $10-\mu \mathrm{M}$ peptide for $2 \mathrm{~h}$. Target cells were labeled with ${ }^{51} \mathrm{Cr}$ (NEN Life Science Products, Boston, MA) for $1 \mathrm{~h}$, washed then co-cultured with CTLs for $4 \mathrm{~h}$. Specific lysis was calculated using the following formula: (where $\mathrm{cpm}$ is counts per minute): $\%$ release $=$ $100 \times(\mathrm{cpm}$ experiment-cpm spontaneous release $) /(\mathrm{cpm}$ maximum release-cpm spontaneous release).

\section{Generation of recombinant fusion proteins}

Antigen coding regions were transferred to vectors for stable transfection of CHO-S cell lines for expression and subsequent purification of anti-CD40-cyclin D1-pep and control hIgG4-cyclin D1-pep as described previously [55]. The control hIgG4 $\mathrm{H}$ chain variable and constant region was gb|BC025985.1| residues 19-1437 with T778C, A780C, and CTG at 779-801 to GAA changes. The control hIgG4 L chain variable and constant region was derived from clone CS0DI041YP06 (Invitrogen). Two sets of antibody-antigen fusion proteins were produced, one with cyclin D1 (NP_444284.1) residues 1-48 appended to the $\mathrm{H}$ chain $\mathrm{C}$-terminus (pepA) and the other with residues 49-295 appended to the $\mathrm{H}$-chain C-terminus (pepB). 
Efficient expression of the prototype vaccines was only obtained when the cyclin D1 peptide regions were flanked by the glycosylated flexible linker sequences ASQTPTNTIS VTPTNNSTPTNNSNPKPNPAS and ASTNGSITVAATAP TVTPTVNATPSAAAS [44].

\section{Accession codes of CD40-targeting antibody}

The 12E12 hybridoma is ATCC PTA 9854. The chimeric CD4012E12 L and CD4012E12 H chain sequences are GenBank HQ738667 and HQ738666, respectively.

\section{Statistical analysis}

The local median regression method was used to set up a positive cutting line for cytokine production. Median plus 5 multiplied median absolute deviation (MAD) was considered statistically significant [56]. Unless otherwise indicated, the value of median plus 5 MAD was shown.

\section{Additional files}

Additional file 1: Table S1. HLA types of healthy donors.

Additional file 2: Figure S1. Cyclin D1-induced T cell responses in a healthy donor. PBMCs isolated from a healthy donor (ND239, HLA-A*0201*01 $\mathrm{B}^{*} 08 * 51 / 78 \mathrm{C} * 07 \mathrm{DRB} 1 * 0301 * 11 \mathrm{DQB} 1{ }^{*} 02^{*} 03$ ) were stimulated with the overlapping 15-mer cyclin D1 peptide library. Median plus 5 multiplied MAD is considered as a positive cutting line. (A) Supernatants were harvested to test cytokine secretion after 48 -h co-culture. NoP is a no peptide negative control. (B) PBMCs were stimulated with cyclin D1 for 8 days and rested in serum-free medium for 3 days before boosting by the same peptide. Intracellular staining of IFN- $\gamma$ was performed $6 \mathrm{~h}$ later. The cells without peptide were used as a negative control. Percentage of $\mathrm{CD}^{+} \mathrm{IFN}-\gamma^{+}$and $\mathrm{CD}^{+} \mathrm{IFN}-\gamma^{+}$population from IFN-y intracellular staining was shown in a two-line graph. Medium plus 5 multiplied MAD is considered as a positive cut-off line (shown as a red dash line for $C D 4^{+} T$ cells and a blue dash line for $C D 8^{+} T$ cells).

\section{Competing interests}

The authors declare that they have no competing interests.

\section{Authors' contributions}

$\mathrm{KP}, \mathrm{JB}$, and WS co-directed the work. All authors read and approved the final manuscript.

\section{Acknowledgements}

The authors thank the patients for volunteering to participate in our study. We are grateful to Lynette Walters for processing of apheresis and blood samples; Cindy Samuelsen for continuous help; and Drs. John S Sullivan and Junnie Yu for critical reading of this manuscript. This work was supported by Baylor Research Institute, Sammons Cancer Center at Baylor University Medical Center, Dallas, TX, and partially by Scientific and Technological Developing Plan of Jilin Province (No. 20120719) and NIH grant KO8CA105064.

\section{Author details}

'Institute of Translational Medicine, the First Hospital, Jilin University, Changchun 130031, China. 'Baylor Institute for Immunology Research and Sammons Cancer Center, Dallas, TX 75204, USA. ${ }^{3}$ The Present address: The Jackson Laboratory for Genomics Medicine, Farmington, CT, USA. ${ }^{4}$ The Present address: AstraZeneca Pharmaceuticals LP, Gaithersburg, MD, USA.

Received: 17 January 2015 Accepted: 24 March 2015

Published online: 14 April 2015

\section{References}

1. Foran JM, Cunningham D, Coiffier B, Solal-Celigny P, Reyes F, Ghielmini M, et al. Treatment of mantle-cell lymphoma with rituximab (chimeric monoclonal anti-CD20 antibody): analysis of factors associated with response. Ann Oncol. 2000;11 Suppl 1:117-21.

2. Chen $Y$, Wang M, Romaguera J. Current regimens and novel agents for mantle cell lymphoma. Br J Haematol. 2014.

3. Dreyling, M., et al. Update on the molecular pathogenesis and targeted approaches of mantle cell lymphoma (MCL) - summary of the 12 annual conference of the EUROPEAN MCL NETWORK. Leuk Lymphoma, 2014. p. 1-26.

4. Williams ME, Dreyling MH, Kahl BS, Leonard JP, O'Connor OA, Press OW, et al. Mantle cell lymphoma: report of the 2009 mantle cell lymphoma consortium workshop. Leuk Lymphoma. 2010;51(3):390-8.

5. Dietrich $\mathrm{S}$ et al. Outcome and prognostic factors in patients with mantle-cell lymphoma relapsing after autologous stem-cell transplantation: a retrospective study of the European Group for Blood and Marrow Transplantation (EBMT). Ann Oncol. 2014;25(5):1053-8.

6. Qi CF, Xiang S, Shin MS, Hao X, Lee CH, Zhou JX, et al. Expression of the cyclin-dependent kinase inhibitor p27 and its deregulation in mouse B cell Iymphomas. Leuk Res. 2006;30(2):153-63.

7. Jares P, Campo E. Advances in the understanding of mantle cell lymphoma. Br J Haematol. 2008;142(2):149-65.

8. Salaverria I, Royo C, Carvajal-Cuenca A, Clot G, Navarro A, Valera A, et al. CCND2 rearrangements are the most frequent genetic events in cyclin D1(-) mantle cell lymphoma. Blood. 2013;121(8):1394-402.

9. Chuang SS, Huang WT, Hsieh PP, Tseng HH, Campo E, Colomer D, et al. Mantle cell lymphoma in Taiwan: clinicopathological and molecular study of 21 cases including one cyclin D1-negative tumor expressing cyclin D2. Pathol Int. 2006;56(8):440-8.

10. Fu K, Weisenburger DD, Greiner TC, Dave S, Wright G, Rosenwald A, et al. Cyclin D1-negative mantle cell lymphoma: a clinicopathologic study based on gene expression profiling. Blood. 2005;106(13):4315-21.

11. Seto M. Cyclin D1-negative mantle cell lymphoma. Blood. 2013;121(8):1249-50.

12. Bacher $U$ et al. Cyclin D1 (CCND1) messenger RNA expression as assessed by real-time PCR contributes to diagnosis and follow-up control in patients with mantle cell lymphoma. Exp Hematol. 2013

13. Soverini $S$ et al. Cyclin D1 overexpression is a favorable prognostic variable for newly diagnosed multiple myeloma patients treated with high-dose chemotherapy and single or double autologous transplantation. Blood. 2003;102(5):1588-94.

14. Sauerbrey A, Häfer R, Zintl F, Volm M. Analysis of cyclin D1 in de novo and relapsed childhood acute lymphoblastic leukemia. Anticancer Res. 1999;19(1B):645-9.

15. Bosch F, Campo E, Jares P, Pittaluga S, Muñoz J, Nayach I, et al. Increased expression of the PRAD-1/CCND1 gene in hairy cell leukaemia. $\mathrm{Br} J$ Haematol. 1995;91(4):1025-30

16. Arber $\mathrm{N}$ et al. Increased expression of the cyclin D1 gene in Barrett's esophagus. Cancer Epidemiol Biomarkers Prev. 1996;5(6):457-9.

17. Arber N, Hibshoosh H, Moss SF, Sutter T, Zhang Y, Begg M, et al. Increased expression of cyclin D1 is an early event in multistage colorectal carcinogenesis. Gastroenterology. 1996;110(3):669-74.

18. Ratschiller D, Heighway J, Gugger M, Kappeler A, Pirnia F, Schmid RA, et al. Cyclin D1 overexpression in bronchial epithelia of patients with lung cancer is associated with smoking and predicts survival. J Clin Oncol. 2003;21(11):2085-93.

19. Weinschenk T, Gouttefangeas C, Schirle M, Obermayr F, Walter S, Schoor O, et al. Integrated functional genomics approach for the design of patientindividual antitumor vaccines. Cancer Res. 2002;62(20):5818-27.

20. Gladden AB, Diehl JA. Location, location, location: the role of cyclin D1 nuclear localization in cancer. J Cell Biochem. 2005;96(5):906-13.

21. Gautschi O, Ratschiller D, Gugger M, Betticher DC, Heighway J. Cyclin D1 in non-small cell lung cancer: a key driver of malignant transformation. Lung Cancer. 2007;55(1):1-14.

22. Dengjel J, Decker P, Schoor O, Altenberend F, Weinschenk T, Rammensee $H G$, et al. Identification of a naturally processed cyclin D1 T-helper epitope by a novel combination of HLA class II targeting and differential mass spectrometry. Eur J Immunol. 2004;34(12):3644-51.

23. Kondo E, Maecker B, Weihrauch MR, Wickenhauser C, Zeng W, Nadler LM, et al. Cyclin D1-specific cytotoxic T lymphocytes are present in the repertoire of cancer patients: implications for cancer immunotherapy. Clin Cancer Res. 2008;14(20):6574-9. 
24. Dao T, Korontsvit T, Zakhaleva V, Haro K, Packin J, Scheinberg DA. Identification of a human cyclin D1-derived peptide that induces human cytotoxic CD4 T cells. PLoS One. 2009;4(8), e6730.

25. Armstrong MJ, Robins GG, Howdle PD. Recent advances in coeliac disease. Curr Opin Gastroenterol. 2009;25(2):100-9.

26. Wang $M$, Sun L, Qian J, Han X, Zhang L, Lin P, et al. Cyclin D1 as a universally expressed mantle cell lymphoma-associated tumor antigen for immunotherapy. Leukemia. 2009;23(7):1320-8.

27. Dougan, $M$, Dranoff $G$. The immune response to tumors. Curr Protoc Immunol. 2009. Chapter 20: p. Unit 2011

28. Palucka AK, Ueno H, Fay JW, Banchereau J. Taming cancer by inducing immunity via dendritic cells. Immunol Rev. 2007;220:129-50.

29. Flacher $V$, Tripp CH, Stoitzner P, Haid B, Ebner S, Del Frari B, et al. Epidermal Langerhans cells rapidly capture and present antigens from C-type lectin-targeting antibodies deposited in the dermis. J Invest Dermatol. 2010;130(3):755-62.

30. Sancho D, Mourão-Sá D, Joffre $O P$, Schulz O, Rogers NC, Pennington DJ, et al. Tumor therapy in mice via antigen targeting to a novel DC-restricted C-type lectin. J Clin Invest. 2008;118(6):2098-110.

31. Birkholz K, Schwenkert M, Kellner C, Gross S, Fey G, Schuler-Thurner B, et al. Targeting of DEC-205 on human dendritic cells results in efficient MHC class II-restricted antigen presentation. Blood. 2010;116(13):2277-85

32. Bozzacco L, Trumpfheller C, Siegal FP, Mehandru S, Markowitz M, Carrington $M$, et al. DEC-205 receptor on dendritic cells mediates presentation of HIV gag protein to $\mathrm{CD} 8^{+} \mathrm{T}$ cells in a spectrum of human $\mathrm{MHC}$ I haplotypes. Proc Natl Acad Sci U S A. 2007;104(4):1289-94.

33. Klechevsky E, Flamar AL, Cao Y, Blanck JP, Liu M, O'Bar A, et al. Crosspriming $\mathrm{CD}^{+} \mathrm{T}$ cells by targeting antigens to human dendritic cells through DCIR. Blood. 2010;116(10):1685-97.

34. Delneste Y, Magistrelli G, Gauchat J, Haeuw J, Aubry J, Nakamura K, et al. Involvement of LOX-1 in dendritic cell-mediated antigen cross-presentation. Immunity. 2002;17(3):353-62.

35. Figdor CG, van Kooyk Y, Adema GJ. C-type lectin receptors on dendritic cells and Langerhans cells. Nat Rev Immunol. 2002;2(2):77-84.

36. Geijtenbeek TB, van Vliet SJ, Engering A, 't Hart BA, van Kooyk Y. Self- and nonself-recognition by C-type lectins on dendritic cells. Annu Rev Immunol. 2004;22:33-54

37. Brown GD. Dectin-1: a signalling non-TLR pattern-recognition receptor. Nat Rev Immunol. 2006;6(1):33-43.

38. Singh J, Garber E, Van Vlijmen H, Karpusas M, Hsu YM, Zheng Z, et al. The role of polar interactions in the molecular recognition of CD40L with its receptor CD40. Protein Sci. 1998;7(5):1124-35.

39. van Kooten C, Banchereau J. CD40-CD40 ligand. J Leukoc Biol. 2000;67(1):2-17.

40. Banchereau J, Steinman RM. Dendritic cells and the control of immunity. Nature. 1998;392(6673):245-52.

41. Cella M, Scheidegger D, Palmer-Lehmann K, Lane P, Lanzavecchia A, Alber $\mathrm{G}$. Ligation of CD40 on dendritic cells triggers production of high levels of interleukin-12 and enhances T cell stimulatory capacity: T-T help via APC activation. J Exp Med. 1996;184(2):747-52.

42. Xu H, Zhao G, Huang X, Ding Z, Wang J, Wang $X$, et al. CD40-expressing plasmid induces anti-CD40 antibody and enhances immune responses to DNA vaccination. J Gene Med. 2010;12(1):97-106.

43. Schjetne KW, Fredriksen AB, Bogen B. Delivery of antigen to CD40 induces protective immune responses against tumors. J Immunol. 2007;178(7):4169-76.

44. Flamar AL et al. Targeting concatenated HIV antigens to human CD40 expands a broad repertoire of multifunctional $\mathrm{CD}^{+}$and $\mathrm{CD} 8^{+} \mathrm{T}$ cells. AIDS. 2013.

45. Palucka K, Banchereau J. Cancer immunotherapy via dendritic cells. Nat Rev Cancer. 2012;12(4):265-77.

46. Vigneron N, Stroobant V, Van den Eynde BJ, van der Bruggen P. Database of T cell-defined human tumor antigens: the 2013 update. Cancer Immun. 2013;13:15.

47. Uram JN, Black CM, Flynn E, Huang L, Armstrong TD, Jaffee EM. Nondominant CD8 $T$ cells are active players in the vaccine-induced antitumor immune response. J Immunol. 2011;186(7):3847-57.

48. Hu X, Chakraborty NG, Sporn JR, Kurtzman SH, Ergin MT, Mukherji B. Enhancement of cytolytic T lymphocyte precursor frequency in melanoma patients following immunization with the MAGE-1 peptide loaded antigen presenting cell-based vaccine. Cancer Res. 1996;56(11):2479-83.
49. Noguchi M, Sasada T, Itoh K. Personalized peptide vaccination: a new approach for advanced cancer as therapeutic cancer vaccine. Cancer Immunol Immunother. 2013;62(5):919-29.

50. Yamada A, Sasada T, Noguchi M, Itoh K. Next-generation peptide vaccines for advanced cancer. Cancer Sci. 2013;104(1):15-21.

51. Bonifaz $L$ et al. Efficient targeting of protein antigen to the dendritic cell receptor DEC-205 in the steady state leads to antigen presentation on major histocompatibility complex class I products and peripheral $\mathrm{CD}^{+} \mathrm{T}$ cell tolerance. J Exp Med. 2002;196(12):1627-38.

52. Bonifaz LC, Bonnyay DP, Charalambous A, Darguste DI, Fujii S, Soares H, et al. In vivo targeting of antigens to maturing dendritic cells via the DEC-205 receptor improves T cell vaccination. J Exp Med. 2004;199(6):815-24.

53. Hawiger D, Inaba K, Dorsett Y, Guo M, Mahnke K, Rivera M, et al. Dendritic cells induce peripheral T cell unresponsiveness under steady state conditions in vivo. J Exp Med. 2001;194(6):769-79.

54. Sadovnikova E, Jopling LA, Soo KS, Stauss HJ. Generation of human tumorreactive cytotoxic T cells against peptides presented by non-self HLA class I molecules. Eur J Immunol. 1998;28(1):193-200.

55. Li D, Romain G, Flamar AL, Duluc D, Dullaers M, Li XH, et al. Targeting self- and foreign antigens to dendritic cells via DC-ASGPR generates IL-10-producing suppressive CD4 ${ }^{+}$T cells. J Exp Med. 2012;209(1):109-21.

56. Fan J, Hall P. On curve estimation by minimizing mean absolute deviation and its implications. Ann Stat. 1994;22(2):867-85.

\section{Submit your next manuscript to BioMed Central and take full advantage of:}

- Convenient online submission

- Thorough peer review

- No space constraints or color figure charges

- Immediate publication on acceptance

- Inclusion in PubMed, CAS, Scopus and Google Scholar

- Research which is freely available for redistribution 